\section{Gilbert Yale Steiner}

Gilbert Yale Steiner, an accomplished student of social policy and an influential director of the Brookings Institution's Governmental Studies program, died on March 1, 2006, in Washington, D.C., at the age of 81 .

Born in Brooklyn, he earned bachelor's and master's degrees from Columbia University in the 1940s, after being discharged from the Army, and then migrated to the University of Illinois to study for a Ph.D. After completing the doctorate, he was named to the Illinois faculty in 1950. His doctoral dissertation on congressional conference committees was published by the University of Illinois Press in 1951.

There followed a period in which he worked on state and local government. An early monograph, Legislation by Collective Bargaining (1951), published by the university's Institute of Labor and Industrial Relations, painstakingly examined the use of the "agreed bill" in Illinois labor legislation since 1911. An agreed bill was one in respect to which "representatives of labor and management seek to agree on the terms of legislation prior to formal legislative enactment." The purpose of this inquiry was "to consider the conditions under which it is feasible to use an agreed bill; its adaptability to the needs and problems of labor, of employers, of the legislature; its growth or deterioration and the reasons therefore." This was an early indication of Gil's commitment to bringing a practical social science to bear on attacking a "social problem," in this case conflict between labor and management.

With the aid of a grant from the Social Science Research Council, Gil did an intensive study of the committee system of the Illinois legislature during its 1957 session. This effort laid the foundation for a chapter in Legislative Politics in Illinois (University of Illinois Press, 1960), a book which he co-authored with Samuel K. Gove. The book's preface contains a scrupulous accounting of the authors' credentials, which in Gil's case included the following remarkable list of experiences: staff associate with the Legislative Commission on Municipal Revenue; consultant to the Election Laws Commission; research associate to the Illinois Legislative Council; staff director of the Northeastern Illinois Metropolitan Area Local Governmental Services Commission; consultant to the Cities and Vil- lages Municipal Problems Commission; co-director of the staff of the Chicago Home Rule Commission; legislative consultant to the City of Chicago; and consultant to the Illinois Municipal League.

In 1958, Gil became director of the university's Institute of Government and Public Affairs, which gave public policy advice to the state and local governments of Illinois and brought him into contact with the state's political leaders. Later, at Brookings, he would wryly recall receiving instruction in the realities of politics from Governor Otto Kerner. In 1960 he was staff director of Public Higher Education in Illinois (Springfield, 1961), a study in which faculty members of seven different institutions of higher education in the state collaborated in making recommendations for a 15-year plan. The work was done under a six-month deadline, and must have tested his skill as both a diplomat and a coordinator. Finally, in 1966 Loyola University published his monograph, Metropolitan Government and the Real World: The Case of Chicago. This thorough immersion in the politics and government of a major state was good training for later work in Washington. Gil knew the American federal system and American politics from the ground up.

With publication in 1966 of Social Insecurity: The Politics of Welfarewhich appeared in the Rand-McNally American Politics Research Series edited by Aaron Wildavsky_-Gil's academic career turned toward national affairs and also toward welfare, which henceforth would be his primary field of policy expertise. Here as well, there was a firm practical grounding in the Illinois experience. He opened the preface by explaining: "This book has been written because I could not find one like it when I was involved in the events described in Chapter VIII. As a temporary special assistant to the Governor of Illinois, I happened on the scene when public assistance policy became a critical issue. It was not possible, however, to understand public assistance in a political context from the existing literature." Chapter VIII is a deeply informative and incisive account of the failure of Illinois to meet its public assistance obligations in 19621963, when "a Democratic Governor and a Republican legislature took turns in attempting to hold back relief funds, with emergency surplus food stations and hunger marches the eventual result." The book as a whole supplied the context for welfare politics that Gil had found lacking. It appeared as the politics of Aid to Dependent Children was intensifying nationwide and established him for many years as a leading expert on the subject among political scientists, even as others followed in his footsteps.

The move to Brookings, which also occurred in 1966, was a logical next step in that Brookings was founded as a rough counterpart at the national level to the numerous state-based institutes of government such as those he had headed in Illinois. Within two years, he succeeded George Graham as director of Governmental Studies, one of Brookings's three major research programs. (The other two are on economics and foreign policy.) In 1969, he briefly returned to the University of Illinois to deliver the Edmund J. James Lecture in Government, "Welfare Options and Welfare Politics." His conclusion was that "the ideal should be a single, comprehensive, nationally financed and administered program of promptly and efficiently paid cash benefits meeting full minimum need in a fashion that gives recipients normal freedom to accept or reject casework services and that does not coerce mothers of small children to work." That ideal would continue to guide his writings on welfare policy.

Governmental Studies under Gil is recalled by many of its participants as a golden era in the life of that program. Brookings was flourishing. The institution was ably led by the economist Kermit Gordon, an urbane, sophisticated New Frontiersman who had served Presidents Kennedy and Johnson as director of the Bureau of the Budget, predecessor of today's Office of Management and Budget (OMB). It was Washington's preeminent think tank, only beginning to be seriously challenged by more conservative rivals. It was well financed by both income from an endowment and foundation grants, which meant that staff members were not under pressure to raise money. Gil's mode of operation was to hire scholars whom he judged to be talented and to give them a great deal of freedom to design their own projects, within the bounds, of course, of Brookings' mission to improve government institutions and public policy. The result was that the program rose in scholarly distinction and produced a number of books that have survived as classics.

From Graham, Gil inherited a major project, Studies in Presidential Selection, 
which fell within a tradition of the Governmental Studies Program. Between 1970 and 1976, Brookings published eight books in this series, among them Voting for President: The Electoral College and the American Political System by Wallace S. Sayre and Judith H. Parris; Perspectives on Presidential Selection, edited by Donald R. Matthews; and The Party's Choice by Matthews and William R. Keech.

Gil also inherited from Graham two senior staff members who would stay for some years. David T. Stanley produced books on bankruptcy (with Marjorie Girth, 1971), the higher civil service (1971), managing local government under union pressure (1972), and the parole system (1976). The superbly self-taught political scientist James L. Sundquist, a Democratic Party activist and former deputy undersecretary of agriculture, became the program's workhorse and one of Brookings's best-selling authors. He began by writing Politics and Policy: The Eisenhower, Kennedy, and Johnson Years (1968) and stayed to produce five other books, including The Dynamics of the Party System (1973 and 1983), The Decline and Resurgence of Congress (1981), and Constitutional Reform and Effective Government (1986 and 1992).

Gil hired the social psychologist Leonard Goodwin, who wrote Do the Poor Want to Work? (1972); Gary Orfield, who wrote Must We Bus? (1978); Hugh Heclo, who wrote A Government of Strangers: Executive Politics in Washington (1977); Donald L. Horowitz, who wrote The Courts and Social Policy (1977); Chester E. Finn, Jr., who wrote Scholars, Dollars, and Bureaucrats (1978); and Daniel Mazmanian, who, after contributing a book on third parties to the presidential elections project, stayed to write Can Organizations Change? Environmental Protection, Citizen Participation, and the Corps of Engineers (with Jeanne Nienaber, 1979). These authors all left Brookings for outstanding careers in other venues, but several of Gil's recruits served for longer times and more titles.

From Yale's political science faculty, Gil recruited Herbert Kaufman. Renowned as a student of public administration for The Forest Ranger, Kaufman was a guest scholar at Brookings in 1967-1968, and had found his visit there "most enjoyable, the staff ... extraordinarily lively and interesting, and access to the government through the institution ... excellent." Moving in 1969 to the staff, which thereby was made even more lively and interesting, Kaufman published four Brookings books, beginning with Administrative Feedback (1973) and ending with The Administrative Behavior of Federal Bureau Chiefs (1981).

Gil recruited Stephen Hess, a prolific author, resident of the capital, and veteran of the Eisenhower and Nixon administrations, to analyze the presidency. Hess wrote two editions of The Presidential Campaign (1978 and 1988), three editions of Organizing the Presidency (1976, 1988, and 2002), and six books in a series on the press called Newswork, beginning with The Washington Reporters (1981) and ending with Through Their Eyes: Foreign Correspondents in the United States (2005), among other titles. Longest-serving of the Steiner staff recruits, he became a senior fellow emeritus in 2004, but continued to write, to have an office at Brookings, to appear frequently as a television commentatorand "daily to be grateful to Gil for bringing me to Brookings."

Gil re-hired Richard P. Nathan, an inand-outer who was an associate director of OMB in the Nixon administration. The two had originally arrived at Brookings simultaneously, in the fall of 1966. Nathan then left to serve in government, but Gil brought him back. With Brookings as a base, the entrepreneurial and energetic Nathan developed the method of field network studies to assess the nationwide impact of federal government programs. His talented staff became an organization within the organization. The main publications were Monitoring Revenue Sharing by Nathan, Allen D. Manvel, Susannah E. Calkins and Associates (1975) and Revenue Sharing: The Second Round by Nathan, Charles F.

Adams, Jr., and Associates (1977).

Nathan would continue his work with field networks and implementation studies in other places, particularly the Rockefeller Institute of Government in New York State.

Gil knew the academic work of Martha Derthick because it overlapped with his own work on welfare and federalism. He brought her from the faculty of Boston College to do a study of regional organizations, which became Between State and Nation (with the assistance of Gary Bombardier, 1974). She stayed to write Uncontrollable Spending for Social Services Grants (1975); Policymaking for Social Security (1979); and The Politics of Deregulation (1985). The book on deregulation was co-authored with Paul J. Quirk, who joined the Brookings staff to work on it.

When Gordon died in 1976, the Brookings trustees chose Gil to be acting president and Sundquist became acting director of the program. A. James Reichley, who would write Religion in American Public Life (1985), and Joel
Aberbach, who would write Keeping A Watchful Eye: The Politics of Congressional Oversight (1990), joined the program at that time. After the trustees in 1977 named Bruce MacLaury to succeed Gordon, Gil returned to being a senior fellow and Sundquist was named director. In 1978, he was followed by Derthick, who served for five years before leaving in 1983 for the University of Virginia. Gil retired as a full-time scholar in 1989 and was named senior fellow emeritus. Brookings-based friendships continued beyond his retirement. Reichley, like Gil, lived in Washington's Maryland suburbs, and literally to the time of Gil's death, long after they had ceased going to offices at Brookings, the two were monthly lunch companions, joined sometimes by Sundquist. Gil and Donna Verdier, who had been his secretary and administrative assistant but had left Brookings to raise children, swapped birthday lunches for more than 20 years.

As an active staff member in the 1980s, Gil "looked after individuals and worried about their projects," Peter Skerry, a visiting fellow and later a nonresident fellow, recalls. Acknowledgments and dedications in Brookings books attest to his continuing influence. Thus, Judges and Legislators, edited by Robert A. Katzmann (1988), contains Katzmann's testimony that "the wise counsel of Gilbert Y. Steiner ... has been indispensable from the outset." Skerry's Counting on the Census?, which Brookings published in 2000, was dedicated to Gil. The Steiner era might be said to extend all the way to Kent Weaver's authoritative Ending Welfare as We Know It (2000), with its dedication to Gil (as well as to Brookings veterans Heclo and Derthick, the three generously characterized as "my teachers"). Weaver's book is a leading example of the painstaking, in-depth analysis of policy processes that Gil had fostered as program director.

"Gotta dig!" Nathan recalls as an imperative. "What was distinctive about Gil was he was always questioning. He didn't just take it all in. He took it in with grains of salt-indeed, more than grains. It was that 'You're-full-of-it' look that made me want to dig. Maybe it was just for me, but I think it was his overweening intellectual honesty." Despite the deep commitment to an institution that originated in Americans' optimistic quest for good governmentand that expected its authors to conclude their studies with affirmative recommendations-Gil was also realistic. Whether he was assessing metropolitan government in Chicago, the ameliorative worth of family policy, or the potential productivity of a job candidate who had 
taken too long to complete a Ph.D., he was not a man to entertain illusions.

Life in the Brookings of the 1970s sometimes seemed too good to be true. It could even seem indulgent. Sundquist recalls his sense of surprise when, having finished a project, he proposed to Gil three choices for a next one and solicited advice on which would best suit Governmental Studies and Brookings. Gil responded that scholars do their best work when they are most engaged, and Sundquist should do whatever he most wanted to.

Nonetheless, as Nathan's recollection suggests, Governmental Studies under Gil was not invariably indulgent. Spare of frame and terse of phrase, he was disciplined, frugal, and exacting. His humor, often displayed, was dry and ironic. Aberbach recalls a conversation about the danger of weight gain in middle age in which Gil mischievously boasted that he could still fit into his bar mitzvah suit. Aberbach recalls as well their shared experience of an ophthalmologist who typically kept his patients cooling their heels. Tiring of this, Gil responded to the man's bill with a bill of his own, seeking compensation for the misspent time. The doctor sent a letter of apology. While director, Gil methodically divided his days into equal halves for administration and his own research.

Gil expected staff members to work hard, to do the projects they had proposed to do rather than something else that might have struck their fancy along the way, and to complete work in a timely fashion even if he was not so naïve as to set deadlines. He too worked hard, as the list of his own Brookings publications attests: The State of Welfare (1971); The Children's Cause with Pauline H. Milius (1976); The Futility of Family Policy (1981); editor, The Abortion Dispute and the American System (1983); and Constitutional Inequality: The Political Fortunes of the Equal Rights Amendment (1985). Manuscripts were subject to thorough peer review before being sent to Brookings' president for approval, and not everything passed the test, either with Gil or with Kermit Gordon. But the tests they applied were scholarly, not political. There was never any pressure to satisfy funding sources or Washington fashions.

Although the book titles listed above suggest that the program's scholarly output was in fact varied, veterans of the Steiner era tend to identify it with an emphasis on a careful, empirical inquiry into policies and policy processes, rendered in accessible, non-technical prose. Upon learning of Gil's death, Quirk wrote: "I've thought of Gil many times over the years. Every once in a while it occurs to me how sensible it is to write books about the politics and substance of a policy issue, with a view toward recommending what to do." Like many political scientists, Quirk first became affiliated with Brookings as a research fellow in Governmental Studies with a year of residence to work on a doctoral dissertation. Among research fellows during the Steiner years were many who went on to make signal contributions to the study or practice of American government, including Jeffrey Berry, Judith Feder, John Ferejohn, Mark Nadel, Bruce Oppenheimer, and James Pfiffner.

Testimonials from Mazmanian and from Heclo suggest that Gil had a particularly powerful impact on very young scholars who came to the staff soon after completing graduate study. Mazmanian, who left Brookings 30 years ago, wrote:

I have many fond memories of my days at Brookings and Gil's extraordinary impact on my life and career... Gil perceived my greenness and took me under wing and took it upon himself to challenge me to think and write at a level not previously achieved. While he was always the keen critic, he seldom showered you (at least me) with compliments. But he did invite me to stay on at Brookings following the presidential study project as a member of the regular staff, and he gave me the truly unique opportunity to 'write a proposal' on what I considered to be an important policy issue worthy of Brookings analysis.... I believe it was the Brookings orientation and Washington experience that headed me down the path of policy analysis, which I have pursued to this day.... .

For me, Gil Steiner was mentor, friend, critic, and ever-demanding in insisting that our work as researchers and scholars be policy relevant. Theory alone was important, but a more immediate return to society by way of improving the policy process and policy in specific areas was his true commitment, and it rubbed off; it became mine.... he was at the forefront of the policy movement in our profession and for the betterment of society. His modeling has stayed with me ... and I have done my best to pass it along to my students over the years since.

Heclo, who at the time was a newly minted Yale Ph. D., recalls:

By responding to an essay competition for one of the Presidential Selection volumes, I came into the orbit of Gil and the Brookings Institution in 1972. It was the best thing that ever happened to me professionally.... Here, out of the blue it seemed, was Gil Steiner asking me about what research ideas I might have if I came to Brookings. They would expect something meeting the Institution's standards of quality and relevance. Was such barefaced intellectual honesty for real? I signed up.

During the next few months my job was to get a book proposal past Gil's devotion to the doctrine of strict scrutiny. As I drafted and re-drafted what became A Government of Strangers, he brought in the likes of my far more senior colleagues Jim Sundquist, Herb Kaufman, and Dick Nathan. In all of this there was never a mention of doing something that could get outside funding, of partisan angles, or political sensitivities (although we were in the middle of the unfolding Watergate disaster). The only questions were always on the merits of the idea and how it could be done. When Gil took me to the Board of Trustees to present the proposal, he let me do the talking. But there he was in my corner, and I have rarely felt so proud.

Golden age or not, I was privileged to experience a person and place of genuine intellectual integrity. Gil presided over a little realm of honest collegiality with serious people acting like grownups, in the midst of a city drunk with yearnings for power and status. For all the sharpness of his mind, he was an utterly kind and gentle man. The toughmindedness did not come from any outsized ego. It came from a frank, wholehearted desire to get to the truth of things, and from that vantage point, to see how to do better.

Yet it was not only green scholars like Mazmanian and Heclo who were helped by Gil. Kaufman, who was slightly older than Gil and had come to Brookings from an Ivy League faculty, recalls that "Gil had an extraordinary talent for identifying the strengths and weaknesses of the manuscripts submitted by his colleagues, and the ability, with a few constructive remarks and questions, to send authors back to their drawing boards with clear notions about how to improve their efforts." Kaufman was "inspired by one of his gentle queries to completely rewrite one of my manuscripts." The lesson in thinking and exposition became "a gift that endures."

Committed though he was to Brookings, Gil nonetheless found time to serve 
other organizations whose mission was research in government and public policy. He was a founding member of the board of MDRC (the Manpower Demonstration Research Corporation), which the Ford Foundation and federal agencies together created in 1974 to do policy evaluation. Gil served until 1996, and upon his death, MDRC's president, Gordon L. Berlin, praised his extraordinary integrity and commitment to the organization's mission. Berlin also cited specifically Gil's early championing of measures to assure that people included in research studies were treated with dignity and respect.

Gil was instrumental also in helping Katzmann to create the Governance Institute in 1986. Katzmann joined the Governmental Studies staff after Gil had ceased being director but while he was still an active member. With degrees in both law and political science, Katzmann soon developed a particular interest in fostering comity between the judiciary and the legislature, and undertook to create, along with Judge Frank M. Coffin, an organization with the purpose of "exploring, explaining, and easing problems associated with both the separation and division of powers in the American federal system." Gil lent his support to this endeavor, which retains an office at Brookings, and continued to do so even after Katzmann left Brookings' full-time staff to become a chaired professor of government, law and public policy at Georgetown University and then a judge of the U. S. Court of Appeals for the Second Circuit, based in New York City. The two became fast friends, and Katzmann has left this particularly affectionate tribute:

From my very first day on the Brookings staff in 1981 until his passing, I was a beneficiary of Gil's generous character, critical eye, unerring judgment, and steadfast loyalty. He was that rare friend- $\mathrm{a}$ friend for the chilly winters of life. Gil's fierce integrity, high standards and very example gave strength to his friends and made us better.

He spoke truth to power and was a conscience of any institution of which he was a part. He was a founding director of the Governance Institute and for two decades my colleagues and I counted on his wisdom.

I was never disappointed.

Martha Derthick, University of Virginia Pietro S. Nivola, Brookings Institution

\section{Michael Wallerstein}

Michael Wallerstein, the Charlotte Marion Saden Professor of Political Science at Yale University, died on January 7, 2006, at his home in New Haven. He was just short of his 55th birthday. The cause was glioblastoma multiforme, a brain cancer.

In all of his scholarly endeavors, Michael Wallerstein sought to identify the conditions under which a society can achieve equality, material security, and justice. Deeply committed politically, Wallerstein was never derailed by ideological prejudice. He was the consummate scholar, never satisfied with his own answers. The intellectual puzzles he studied were motivated by some simple facts, and the answers he articulated used rigorous analytic tools. His intellectual influence was both substantive and methodological, thanks to his commitment to using formal and statistical tools of analysis to study important questions within comparative politics and political economy.

Wallerstein was born in Topeka, Kansas in 1951, and raised there and later in Marin County. His undergraduate education took place at Stanford University. He received his Ph.D. from the University of Chicago in 1985. During his graduate career, he crossed the intellectual gulf from political science to Chicago's economics department of Friedman, Stigler, Becker, and Lucas. His graduate work in both disciplines informed all of his later research.

While still a student at the University of Chicago, Wallerstein collaborated with his dissertation advisor, Adam Przeworski, in the study of the strategies of labor movements under democratic conditions. Their work was motivated by the Marxian puzzle that if workers were to gain political rights in the form of suffrage, they would use these rights to confiscate the rich. Capitalists, in response, would protect themselves by subverting democracy with arms. As a result, capitalism and democracy could not coexist.

Yet of course, they did, and Przeworski and Wallerstein authored a series of path-breaking papers that used formal tools of analysis to investigate why. They found that in a capitalist economy, where decisions to invest are a prerogative of the owners of capital, workers face a trade-off between redistribution and economic growth. Because future income depends on economic growth, it is rational for workers to moderate their redistributive demands. In turn, facing moderate demands, the bourgeoisie not only invests but can also live with democracy. As a result, a "democratic class compromise" naturally emerges, at least as long as everyone is sufficiently patient and the economy sufficiently productive.

Wallerstein's doctoral dissertation, which subsequently generated a series of articles, sought to explain the origin and structure of welfare states in small economies. In the spirit of the day, he observed that small economies could not hide behind trade barriers. In turn, in an economy open to trade, any monopolistic mark-up of wages above the world level would result in unemployment. Moreover, openness makes economies vulnerable to fluctuations in world demand. Hence, Wallerstein showed, small open economies must maintain wage discipline and develop an encompassing system of insurance against external shocks.

Most of Wallerstein's later intellectual life was devoted to the two themes he worked on while still a graduate student-namely, wage-setting institutions and the welfare state. Wage-setting institutions, Wallerstein gradually discovered, depended on the structure of trade unions, while an extensive welfare system required specific political institutions and was encouraged by left-wing partisan control of government. His ultimate aim was to understand "egalitarian institutions": labor market and political institutions that in combination generate egalitarian outcomes and insure from random adversities.

Although Przeworski and Wallerstein's analysis of class compromise was purely theoretical, conducted at the level of "capitalist democracy," it was obvious that the Scandinavian Social Democrats were more successful in advancing the welfare of wage-earners than socialist or non-socialist governments in other parts of the developed world. Thus was born Wallerstein's life-long fascination with Scandinavia, crystallized by the year he spent in Norway in 1989-1990, when he began a productive, long-term collaborative relationship with the Norwegian economist Karl Ove Moene.

After completing his graduate education, Wallerstein accepted a position at the University of California at Los Angeles, where he remained for 10 years. At the time, the UCLA political science department was in the process of building a strong group in political economy, of which Wallerstein was a central member. He was active in recruitment, and retained close and affectionate ties for the rest of his life with the political economy colleagues he had from his decade at UCLA.

At UCLA, much of Wallerstein's intellectual attention was devoted to empirical research on trade unions and collective bargaining that arose from his 